\title{
Basic Skills and Competences of Higher National Diploma Computer Science Graduates: An Analysis of Stakeholders Views
}

\author{
Ishaq Rasheed Salimonu* Abdullai Alfa Olayiwola \\ School of Applied Sciences and Technology, Federal Polytechnic Offa, PMB 420, Kwara State, Nigeria
}

This work was funded by Nigeria Tertiary Education Trust Fund under Institution-Based Research Grant (Batch 6 RP Disbursement- TETFUND/DL88/POLY/OFFA/RP/VOL. VI).

\section{Abstract}

This study was motivated by the general opinion or statements from the public and specifically from professional bodies and industries in the country suggesting that tertiary curricula currently being implemented by academic institutions in Nigeria do not provide what is needed by the industry or labour employer. The main objective of the study is to identify skill and competency gaps in the training of Higher National Diploma graduates of computer science or information technology in Nigeria and to provide recommendations on how the identified gaps could be address in the training curriculum. A three-round Delphi questionnaire where the respondents were asked to rate the items on the scale of their importance was used for the study. The results suggest that, there was significant difference in the views of academic and industry participants in the ranking of the skill and competency attributes based on the scale of preference. The current curriculum also aligned with the needs of the industry in terms of the generic skills. The study among others, recommend two generic skills (21 and 25) considered to be of importance by the industry participants be given serious consideration during review of curriculum to improve the employability of the graduates.

Keywords: Basic Skills, Curriculum, Employability, Computer Science

DOI: $10.7176 / \mathrm{JEP} / 12-16-03$

Publication date:June $30^{\text {th }} 2021$

\section{Introduction}

The term basic skills describe set of characteristics and abilities of an individuals to do something well, normally an outcome of acquisition of training and experience which are very important to the wellbeing of an individual, without which he/she cannot really exist (OECD 2018). The concept of basic skills often referred to in the literature as a suitable attributes or knowledge is the core body of knowledge acquired by a person in a specified subject discipline which can be used for the betterment of the society. Therefore, skills are repeated application of know-how or characteristics acquired over time (Snoke \& Underwood 2002; Okolie et al. 2019). Competence on the other hand, is ambiguous in nature and can be applied to various situations with different meaning (Winterton et al. 2006; Abelha et al. 2020; Normal 2003). Therefore, competence as suggested by Mulder et al. (2006), and in line with the context of our study, can be defined as a term "concerned with the meaningful objectives and content of learning that will engender the personal development of students and position them within the domain of knowledge that can best prepare them to function effectively in society". Competences, therefore, plays key roles in the context of higher education and hence its interrelationship with employability (Jackson et al. 2016).

The objectives of polytechnic education in Nigeria is similar to what is obtain in other part of the world is to impart relevant but necessary work skills and competences in prospective Higher National Diploma (HND) students. However, the increasing negative reports from the media, governments, industries, professional bodies, and society indicates higher percentage of youth that passthrough the polytechnics, lack the competences and skills which could not earned them employment or made them self-reliant after graduation (Adebisi 2015). A number of studies has shown that, tertiary curricula do not meet the needs of the industry (Okoye \& Arimonu 2016; Moreno et al. 2012; Jones et al. 2018; Scatalon et al. 2018; Mulder et al. 2006). Therefore, educators, trainers and industry in Computer Science (CS) needs to discover and authenticate the generic characteristics (basic skills) required by prospective employers or industry for graduates who major in CS (Snoke \& Underwood 2002).

This study is to investigate the views of critical stakeholders (academics in the polytechnics and industries) on the basic skills and competences requirements of CS graduates with Higher National Diploma (HND) certificate and determine whether there are perceived difference in the views of academia and the industry and recommend how this gaps if exist can be close through the restructuring of the curriculum of the Polytechnics in the country for CS graduates.

\section{Background}

Studies conducted or investigated on the skills and competences by (Snoke \& Underwood, 2002; Singh, Thambusamy \& Ramy 2014; Adebisi 2015; Sarkar et al. 2016; Okoye \& Arimonu 2016; Messum et al. 2017; 
Dimopoulos 2018; Okolie et al. 2019; Moreno et al. 2012; Jones et al. 2018; Scatalon et al. 2018; Mulder et al. 2006), indicates that there is a gap in the skills and competences achieved by Information Technology/Information Systems/Software Engineering/Cybersecurity/Software Testing graduates compared with what is required by the industry or employers. Study of Snoke et al. (2002), on the generic attributes of information system (IS) graduates, suggests significant correlation between identified generic attributes of an Information Systems graduates and their skills and competences requirement for employability after graduation. Singh et al. (2014), investigated the generic skills from the perspectives of employers and university instructors. Their findings show that instructors and employers were in agreement on some generic attributes of the study and that curriculum meets the needs of the employers. Sarkar et al. (2016), conducted a study on employability of science graduates, the results of the study indicate that, generic skills are of greater importance in workplaces after graduation in comparison to the discipline specific knowledge acquired by the graduate. Study on perceptions of senior managers on graduates of health services management on the employability skills was conducted by (Messum 2017). The result indicates that, both groups agreed on top ten (10) of the generic skills as of most important on the scale of preference.

Dimopoulos (2018), examined the impact of Soft skills as a factor affecting the employability of graduates. The results show that Soft skills of graduates had greater impact on their employability and this equally determined the decisions of employer during the recruitment process. The findings of the study conducted by Shivoro et al. (2018), on the employability attributes (skills) of management sciences profession indicates serious disparity in the views of the stakeholders (employers, lecturer and graduates) on what constitutes the required generic skills that qualified a graduate of management sciences as employable.

Okolie et al. (2019), conducted a study to understand the reasons Higher Education Institutions could not teach generic skills in its graduate courses and how these institutions are able to conceptualize generic skills. The study indicates that, HEIs do not teach generic skills in their curriculum and recommend entrepreneurship education be made compulsory at all levels of educations (Primary, secondary, and tertiary institutions) in other to improve the employability of graduates.

Aasheim et al. (2009), examined the disconnect in the perceptions of academic and industry on the required skills considered of importance for entry-level Information Technology workers. Their findings suggest that there were no significant differences in their perceptions on the required skills, however, emphasis is placed on the broader categories of knowledge/skills in IT curricula by the academics compared to the expectations of the industry regarding same knowledge/skills. Likewise, findings equally suggest difference in their perceived importance of several individual skills/traits.

The study of Moreno et al. (2012), examines whether Software Engineering (SE) curriculum meets the criteria for the job profile as required by the industry and the need to bridge the skills gaps if any in line with the requirements of the industry and international standards for a graduate of SE. The study found that the job profile for a graduate of SE by the industry were not completely meet by the two SE knowledge guidelines provided for their training, hence the need to move from technical to business issues in the training of a graduate of SE in other to close the identified gaps.

The findings of Jones et al. (2018), on the study which examines the knowledge, skills and abilities (KSA) that needs to be acquired by students of Cybersecurity during training in the school and whether the most important KSAs were adequately covered by the curriculum suggest that majority of the KSAs were acquired majorly by the students on the job or as a self-study and not during training at the school. Similarly, Scatalon et al. (2018), conducted a survey of graduates' knowledge gaps in curriculum for Software Testing. The results confirm a deficiency for all topics covered on software testing subjects in practical terms with both negative and positive gaps in relation to the client (Employer) requirements or needs.

Jackson et al. (2016), examines the perceptions of academic and industry as related to the preparedness of graduates of health information management. The study found out that a skills gaps were recognized by employers and educators in the field of health information management and recommend the need to bridge the identified skills gaps.

All these studies as discussed contributes to our understanding of skills gap inherent in the training of graduates of higher institutions in meeting the requirements of the industries in the selected areas computing, however, focus on computer science as a field of study is either scanty or nonexistent. Equally, all the studies reviewed focused on the university graduates to the exclusion of the polytechnic graduates. Therefore, our study is aimed at filing these two identified gaps in other to add to our understanding of this area of research.

\section{Research Method}

The objectives of this study is to determine if there exist gaps in the skills and competences in the training of a polytechnic graduates with HND certificates based on the perceptions of the academics in the polytechnic teaching computer science and the employers in the IT industries. To this end, the study adopted Delphi research design using quantitative method of data collection. This method was used to carefully select experts in CS 
(academics and industry) in an interactive step (Sekaran \& Bougie 2011). This method brings to the fore new issues of the study and equally help achieve consensus among participants who are expert (Hsu \& Sandford 2007; Knighting et al. 2016). This method allows participants to answer questionnaires in three rounds. The essence of this iterative process is to achieve a consensus among the participants about the issues under investigation. Delphi method has been widely used in areas such as business, information system and of recent in IT studies (Skinner et al. 2015). The major advantage of this method is that, the identity of participants will not be revealed during and after the completion of the study. Therefore, participant cannot dominate the other and each participant have unreserved expression of opinions thereby encouraging the participants to admit mistakes if any, by revisiting their earlier judgements on questions asked. Existing questionnaire items relating to the subject matter was adopted and adapted from the study of Snoke \& Underwood (2002), to suit the domain of the study. Academic and industrial participants were selected using multistage cluster random probability sampling methods of data collection. The multistage cluster probability sampling was adopted due to vast nature of the country, reaching all the target population is not visible. Therefore, the method was used to reduce cost, time and efforts as compare to simple random or systematic random sampling. The simple random sampling was then used to select a participant in the chosen cluster in order to mitigate the sampling biases and systematic errors associated to cluster sampling and to achieve generalization of the results to the population (Kumar 2011; Pandey \& Pandey 2015; Alvi 2016; Showkat \& Parveen 2017; MacCallum \& Casey 2017).

\subsection{Selection of Participants}

The study subdivides the country into six geo-political zones, namely North-West, North-East, North-central, South-West, South-East and South-South. At the next stage, the participants from academics was selected from computer science department in two Polytechnics (one federal and one state) in the six geo-political zone of the country (see Table 1). For the IT industries, participants were selected from IT organizations (see Table 2). At the third stage, academic participants were then drawn from the lecturers in each selected polytechnic on a random basis. The same procedure was adopted in the selection of staff in each of the IT organization from the South West and North Central of the country.

Table 1: Polytechnic selected from each Geo-Political zone

\begin{tabular}{|c|c|c|}
\hline Name of Polytechnic & State & Zone \\
\hline $\begin{array}{l}\text { 1. Kaduna Polytechnic, Kaduna. } \\
\text { 2. Kano State Polytechnic, Kano }\end{array}$ & $\begin{array}{ll}\text { 1. Kaduna } \\
\text { 2. Kano }\end{array}$ & North West \\
\hline $\begin{array}{l}\text { 1. Federal Polytechnic Bali, Taraba } \\
\text { 2. Abubakar Tatari Ali Polytechnic, Bauchi }\end{array}$ & $\begin{array}{l}\text { 1. Taraba } \\
\text { 2. } \text { Bauchi }\end{array}$ & North East \\
\hline $\begin{array}{l}\text { 1. Federal Polytechnic Bida } \\
\text { 2. Kogi State Polytechnic, Lokoja }\end{array}$ & $\begin{array}{ll}\text { 1. Niger } \\
\text { 2. Kogi }\end{array}$ & North Central \\
\hline $\begin{array}{l}\text { 1. Federal Polytechnic Ado Ekiti } \\
\text { 2. The Polytechnic Ibadan }\end{array}$ & $\begin{array}{ll}\text { 1. } & \text { Ekiti } \\
\text { 2. } & \text { Oyo }\end{array}$ & South West \\
\hline $\begin{array}{l}\text { 1. Akanu-Ibiam Federal Polytechnic, Afikpo } \\
\text { 2. Abia State Polytechnic, Aba }\end{array}$ & $\begin{array}{l}\text { 1. Ebonyi } \\
\text { 2. Abia }\end{array}$ & South East \\
\hline $\begin{array}{l}\text { 1. Auchi Polytechnic, Auchi } \\
\text { 2. Akwa Ibom State Polytechnic, Ikot Osurua, Ikot -Ekpene }\end{array}$ & $\begin{array}{ll}\text { 1. } & \text { Edo } \\
\text { 2. } & \text { Akwa Ibom }\end{array}$ & South South \\
\hline
\end{tabular}

Table 2: Selected IT Industry and Location

\begin{tabular}{|l|c|}
\hline \multicolumn{1}{|c|}{ Name of IT Company } & Location \\
\hline Tango Digital System & Lagos \\
\hline Webthinker & Lagos \\
\hline Sunnet Systems \& Data Communications & Lagos \\
\hline Cyberspace Ltd & Lagos \\
\hline Mainone IT Professionals Ltd & Lagos \\
\hline India Institute of Hardware Technology & Lagos \\
\hline IT GLOBAL HUB & Lagos \\
\hline Multimedia Graphic \& Web Design & Abuja \\
\hline Skylight Technologies Ltd & Abuja \\
\hline Avsatel Communications & Abuja \\
\hline Backbone Connectivity Network & Abuja \\
\hline Jetcom Integrated Services Ltd & Abuja \\
\hline Profile Technologies Ltd & Abuja \\
\hline
\end{tabular}

The academic and industry participants for the study were accessed for the first round of data collection by physical interactions and filling the prepared questionnaires. For the second and final (third) rounds of data 
collections, the questionnaire was sent to the participants via their emails collected during the first round. The number of responses per each round is as indicated in Table 3 and Figure 1.

Table 3: Rate of Participation per round

\begin{tabular}{|l|c|c|c|c|c|}
\hline & & \multicolumn{2}{|c|}{ Academic } & \multicolumn{2}{c|}{ Industry } \\
\hline & $\begin{array}{c}\text { Total Number of } \\
\text { Participant }\end{array}$ & $\begin{array}{c}\text { Number of } \\
\text { Participant }\end{array}$ & $\begin{array}{c}\text { Percentage } \\
(\mathbf{\%})\end{array}$ & $\begin{array}{c}\text { Number of } \\
\text { Participant }\end{array}$ & $\begin{array}{c}\text { Percentage } \\
(\%)\end{array}$ \\
\hline Round 1 & 194 & 127 & 65 & 67 & 35 \\
\hline Round 2 & 149 & 98 & 66 & 51 & 34 \\
\hline Round 3 & 152 & 101 & 66 & 51 & 34 \\
\hline
\end{tabular}

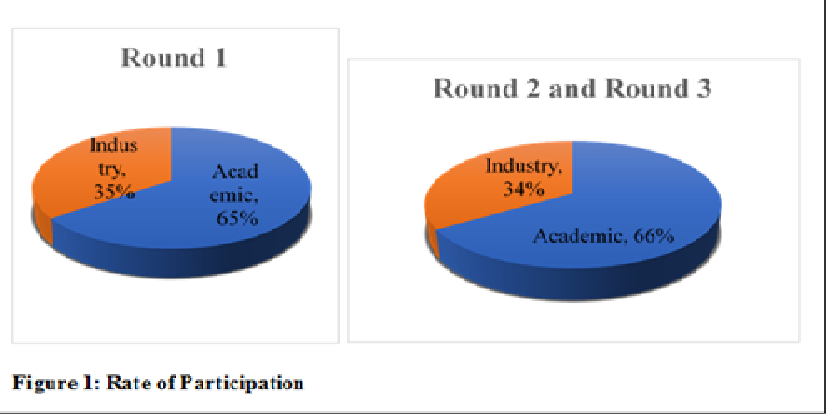

Table 3 and Figure 1 shows that, there was a decrease in the participation of the industry respondents for second and third rounds by one percent. For the first round, 65 percent and 35 percent response rate was achieved for academics and industry respectively. While second and third rounds achieved 66 percent and 34 percent response rate between academics and industry respectively. For each round of data collection, mean and standard deviation were calculated.

\subsection{Data Collection}

For each round of data collection, the participant were asked to rate the skill and competency items using a seven-point Likert scale in the order of importance where $1=$ extremely unimportant, $2=$ unimportant, $3=$ of little importance, $4=$ neutral, $5=$ very important, $6=$ of major importance, and $7=$ extremely important. Space for additional skill competency or comment is provided. Second and third round data collection was achieved through online questionnaire using the participants email address collected during the first round.

At the end of each round, mean and standard deviation of all the responses was calculated using IBM Statistical Package for Social Science (IBM SPSS) 20 for Windows and used to prepared the items for the second-round data collection. All items were retained for the second and third round data collection because none fall below a mean value of 4.00. The result for the third round was used to conclude the study.

\section{Holonic Architecture}

4.1 Result Analysis (Round 1)

4.1.1 Academics

The results of first round is as shown in Table 4. The mean and standard deviation values indicates three (3) out of the twenty-nine items measured had a mean value below 5.00 which shows that respondents on the average are neutral or unsure about (1) Sensitivity to differences in gender, culture and customs; (2) Knowledge of how a business operate, is structured or is orientated; and (3) Adapt to unfamiliar cultures and operate in a socially and culturally diverse environment as items that should determine the competency of an HND graduates in CS.

Table 4: Results of Academic and Industry Respondents (Round 1)

\begin{tabular}{|c|c|c|c|c|c|c|c|}
\hline & $\begin{array}{l}\text { Basic Skills and } \\
\text { Competences }\end{array}$ & Academic & & & Industry & & \\
\hline & & Mean & StDev & Rank & Mean & StDev & Rank \\
\hline 1 & Self-motivation & 5.77 & 1.328 & 1 & 5.12 & 1.482 & 15 \\
\hline 2 & $\begin{array}{l}\text { Retrieve, evaluate and use } \\
\text { relevant information }\end{array}$ & 5.54 & 1.180 & 6 & 5.01 & 1.398 & 18 \\
\hline 3 & $\begin{array}{l}\text { Be able to participate in } \\
\text { continued learning and } \\
\text { intellectual development and } \\
\text { develop critical, reflective, and } \\
\text { creative thinking. }\end{array}$ & 5.76 & 1.264 & 2 & 5.19 & 1.282 & 13 \\
\hline
\end{tabular}




\begin{tabular}{|c|c|c|c|c|c|c|c|}
\hline & $\begin{array}{l}\text { Basic Skills and } \\
\text { Competences }\end{array}$ & Academic & & & Industry & & \\
\hline & & Mean & StDev & Rank & Mean & StDev & Rank \\
\hline 4 & $\begin{array}{l}\begin{array}{l}\text { Analyze, synthesizes } \\
\text { solutions }\end{array} \\
\text { the various } \\
\end{array}$ & 5.27 & 1.027 & 18 & 5.09 & 1.288 & 16 \\
\hline 5 & $\begin{array}{l}\text { Confidence about their ability to learn } \\
\text { independently }\end{array}$ & 5.43 & 1.245 & 10 & 5.09 & 1.300 & 16 \\
\hline 6 & $\begin{array}{l}\text { Consider the quality of the } \\
\text { solution and its timeliness }\end{array}$ & 5.25 & 1.076 & 19 & 5.18 & 1.325 & 14 \\
\hline 7 & $\begin{array}{l}\text { Embrace change and be obliged to } \\
\text { engage in incremental } \\
\text { improvement to keep up with the rapid } \\
\text { change in technology }\end{array}$ & 5.74 & 1.223 & 4 & 5.24 & 1.304 & 11 \\
\hline 8 & $\begin{array}{l}\text { Work as part of a team in a } \\
\text { productive and cooperative } \\
\text { manner. }\end{array}$ & 5.61 & 1.169 & 5 & 5.07 & 1.318 & 17 \\
\hline 9 & $\begin{array}{l}\text { With respect to the Computer } \\
\text { Science (CS) or Information } \\
\text { Technology (IT) discipline be } \\
\text { technologically competent (the } \\
\text { person is able to use the current } \\
\text { technology competently. }\end{array}$ & 5.75 & 1.202 & 3 & 5.28 & 1.300 & 10 \\
\hline 10 & $\begin{array}{l}\text { Value the ethics of the } \\
\text { Information Technology } \\
\text { profession }\end{array}$ & 5.61 & 1.121 & 5 & 5.09 & 1.401 & 16 \\
\hline 11 & Oral communication skills & 5.40 & 1.230 & 12 & 5.28 & 1.300 & 10 \\
\hline 12 & Define problems in a systematic way & 5.37 & 1.060 & 14 & 5.28 & 1.346 & $\mathbf{1 0}$ \\
\hline 13 & Interpersonal skills & 5.28 & 1.180 & 17 & 5.33 & 1.397 & 8 \\
\hline 14 & Work independently & 5.31 & 1.080 & 16 & 5.34 & 1.321 & 7 \\
\hline 15 & Written communication skills & 5.28 & 1.059 & 17 & 5.22 & 1.301 & 12 \\
\hline 16 & $\begin{array}{l}\text { With respect to the CS discipline } \\
\text { possess coherent, extensive, } \\
\text { theoretical and practical } \\
\text { knowledge }\end{array}$ & 5.46 & 1.006 & 8 & 5.34 & 1.309 & 7 \\
\hline 17 & $\begin{array}{l}\text { Ability to reflect on own } \\
\text { strengths and weaknesses }\end{array}$ & 5.23 & 1.183 & 20 & 5.33 & 1.375 & 8 \\
\hline 18 & $\begin{array}{l}\text { Participate in on-going } \\
\text { professional development }\end{array}$ & 5.46 & 1.194 & $8^{*}$ & 5.33 & 1.386 & $8^{*}$ \\
\hline 19 & $\begin{array}{l}\text { Possess a sense of basic curiosity about } \\
\text { technology }\end{array}$ & 5.41 & 1.157 & 11 & 5.36 & 1.432 & 6 \\
\hline 20 & Time management skills & 5.39 & 1.156 & 13 & 5.46 & 1.439 & 5 \\
\hline 21 & $\begin{array}{l}\text { Sensitivity to differences in } \\
\text { gender, culture and customs }\end{array}$ & $4.21^{* *}$ & 1.489 & 24 & 5.24 & 1.447 & 11 \\
\hline 22 & Research skills & 5.44 & 1.089 & 9 & 5.36 & 1.356 & 6 \\
\hline 23 & $\begin{array}{l}\text { Demonstrate practical } \\
\text { knowledge and understanding in at } \\
\text { least one computer language }\end{array}$ & 5.49 & 1.194 & 7 & 5.24 & 1.394 & 11 \\
\hline 24 & $\begin{array}{l}\text { With respect to the CS discipline } \\
\text { possess theoretical and practical } \\
\text { knowledge in at least one } \\
\text { reference discipline }\end{array}$ & 5.43 & 1.081 & 10 & 5.24 & 1.426 & 11 \\
\hline 25 & $\begin{array}{l}\text { Adapt to unfamiliar cultures and } \\
\text { operate in a socially and } \\
\text { culturally diverse environment }\end{array}$ & $4.80^{* *}$ & 1.148 & 23 & 5.30 & 1.467 & 9 \\
\hline 26 & $\begin{array}{l}\text { Knowledge of how a business } \\
\text { operate, is structured or is } \\
\text { orientated }\end{array}$ & $4.91^{* *}$ & 1.151 & 22 & 5.60 & 1.393 & 1 \\
\hline
\end{tabular}




\begin{tabular}{|l|l|l|l|l|l|l|l|}
\hline & $\begin{array}{l}\text { Basic Skills and } \\
\text { Competences }\end{array}$ & Academic & & & Industry & & \\
\hline $\mathbf{2 7}$ & $\begin{array}{l}\text { Understand the profit motive of } \\
\text { business }\end{array}$ & Mean & StDev & Rank & Mean & StDev & Rank \\
\hline $\mathbf{2 8}$ & $\begin{array}{l}\text { With respect to the CS discipline } \\
\text { possess the theoretical and } \\
\text { theoretical knowledge of related } \\
\text { disciplines }\end{array}$ & & 1.147 & $\mathbf{2 1}$ & 5.54 & 1.439 & $\mathbf{2}$ \\
\hline $\mathbf{2 9}$ & Project management skills & .959 & $\mathbf{1 5}$ & 5.51 & 1.397 & $\mathbf{3}$ \\
\hline
\end{tabular}

*(Group share same view on item $), * *($ mean $<5.00)$

The remaining 26 items or measures were considered to be very important (mean rating of 5.00 or greater) but not of major importance or extremely important as determinant of how competent is an HND graduate of CS. Of all the 26 competences rated very important, Self-motivation was rated number one.

4.1.2 Industry

The first-round results for industry (see Table 4) shows that, all the 29 items had mean values of 5.01 and above but less than 6.00. All respondents from the industry considered all measures to be very important and good determinant of competency of an HND graduates of CS. Industry participants rated Knowledge of how a business operate, is structured or is orientated as the most important (mean value of 5.60).

4.1.3 Discussion (Round 1)

From the analyzed data in Table 4, it can be observed that, there was significant differences in the views of academic and industry participants. Academics ranked five attributes of (a) Self-motivation; (b) Be able to participate in continued learning and intellectual development and develop critical, reflective, and creative thinking; (c) With respect to the Computer Science (CS) or Information Technology (IT) discipline be technologically competent (the person is able to use the current technology competently; (d) Embrace change and be obliged to engage in incremental improvement to keep up with the rapid change in technology; (e1) Value the ethics of the information technology profession and (e2) Work as part of a team in a productive and cooperative manner higher on the scale of preference compared to others on the list (Figure 2).

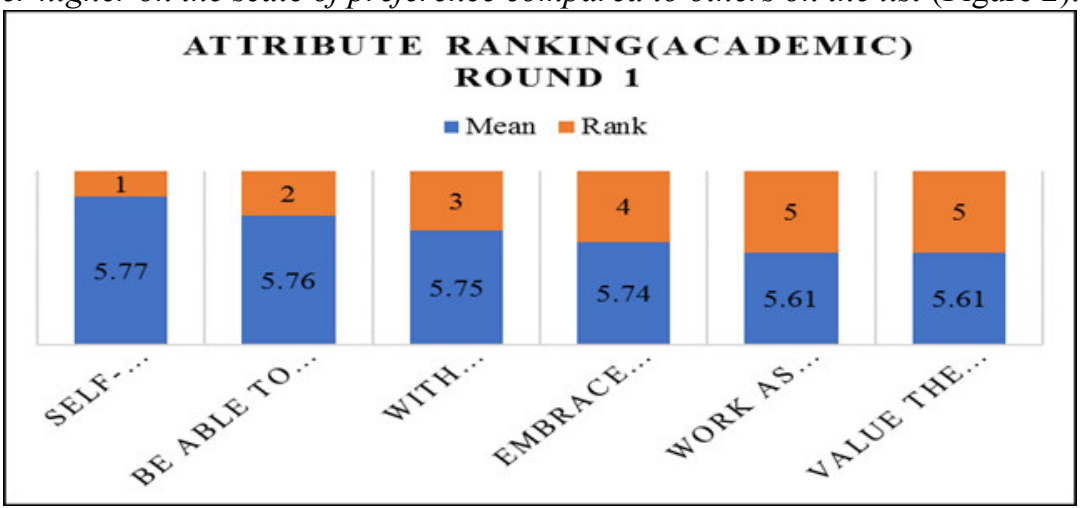

Figure 2: The five highest competency ranking based on the scale of preference by academic

While the industry participants ranked five attributes of (a) Knowledge of how a business operate, is structured or is orientated; (b) Understand the profit motive of business;(c) With respect to the CS discipline possess the theoretical and theoretical knowledge of related disciplines;(d) Project management skills; (e) Time management skills higher than other items on the list.

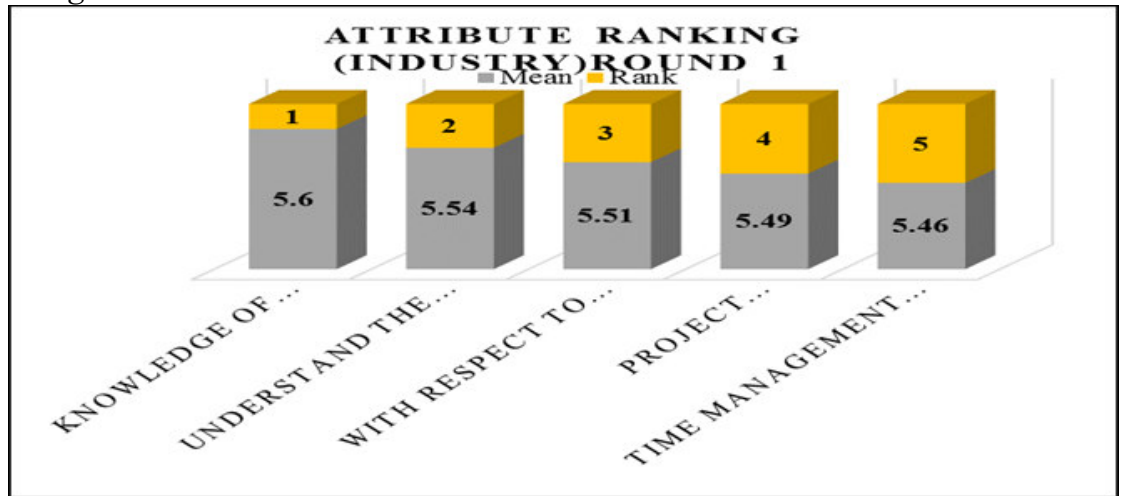

Figure 3: The five highest competency ranking based on the scale of preference by industry 
However, both groups agreed that, an HND CS graduate should be able to participate in on-going professional development which was ranked as $8^{\text {th }}$ on the scale of preference.

\subsection{Result Analysis (Round 2)}

\subsubsection{Academics}

Analysis of the second-round data for the academic participants (See Table 5) revealed as follows:

1. The three items scored below 5.00 in first round was retained in the second round. The participants are still unsure of their importance in determining the competency of a graduate of HND in CS;

2. The remaining twenty-six (26) items indicates that, they are very important (mean value of 5.00 and above) but not of major importance or extremely important;

Compared to the first-round results, self-motivation was equally rated the highest on the scale of preference compared to the remaining twenty-five items.

Table 5: Results of Academic and Industry Respondents (Round 2)

\begin{tabular}{|c|c|c|c|c|c|c|c|}
\hline & Basic Skills and Competences & Academic & & & Industry & & \\
\hline & & Mean & StDev & Rank & Mean & StDev & Rank \\
\hline 1 & Self-motivation & 5.77 & 1.328 & 1 & 5.10 & 1.526 & 11 \\
\hline 2 & $\begin{array}{l}\text { Retrieve, evaluate and use } \\
\text { relevant information }\end{array}$ & 5.54 & 1.180 & 6 & $4.96^{* *}$ & 1.483 & 14 \\
\hline 3 & $\begin{array}{l}\text { Be able to participate in } \\
\text { continued learning and } \\
\text { intellectual development and } \\
\text { develop critical, reflective, and creative } \\
\text { thinking. }\end{array}$ & 5.76 & 1.264 & 2 & 5.18 & 1.506 & 8 \\
\hline 4 & $\begin{array}{l}\text { Analyze, synthesizes the } \\
\text { various solutions }\end{array}$ & 5.27 & 1.027 & 18 & $4.98 * *$ & 1.556 & 13 \\
\hline 5 & $\begin{array}{l}\text { Confidence about their ability to learn } \\
\text { independently }\end{array}$ & 5.43 & 1.245 & 10 & 5.06 & 1.502 & 12 \\
\hline 6 & $\begin{array}{l}\text { Consider the quality of the } \\
\text { solution and its timeliness }\end{array}$ & 5.25 & 1.076 & 19 & 5.16 & 1.567 & 9 \\
\hline 7 & $\begin{array}{l}\text { Embrace change and be } \\
\text { obliged to engage in } \\
\text { incremental improvement to } \\
\text { keep up with the rapid change in technology }\end{array}$ & 5.74 & 1.223 & 4 & 5.20 & 1.536 & 7 \\
\hline 8 & $\begin{array}{l}\text { Work as part of a team in a } \\
\text { productive and cooperative } \\
\text { manner. }\end{array}$ & 5.61 & 1.169 & 5 & 5.10 & 1.526 & 11 \\
\hline 9 & $\begin{array}{l}\text { With respect to the Computer Science (CS) or } \\
\text { Information Technology (IT) discipline be } \\
\text { technologically competent (the person is able } \\
\text { to use the current technology competently) }\end{array}$ & 5.75 & 1.202 & 3 & 5.24 & 1.582 & 6 \\
\hline 10 & $\begin{array}{l}\text { Value the ethics of the } \\
\text { Information Technology } \\
\text { profession }\end{array}$ & 5.61 & 1.121 & 5 & 5.10 & 1.578 & 11 \\
\hline 11 & Oral communication skills & 5.40 & 1.230 & 12 & 5.20 & 1.613 & 7 \\
\hline 12 & $\begin{array}{l}\text { Define problems in a } \\
\text { systematic way }\end{array}$ & 5.37 & 1.060 & 14 & 5.24 & 1.544 & 6 \\
\hline 13 & Interpersonal skills & 5.28 & 1.180 & 17 & 5.25 & 1.547 & 5 \\
\hline 14 & Work independently & 5.31 & 1.080 & 16 & 5.16 & 1.567 & 9 \\
\hline 15 & Written communication skills & 5.28 & 1.059 & 17 & 5.16 & 1.515 & 9 \\
\hline 16 & $\begin{array}{l}\text { With respect to the CS } \\
\text { discipline possess coherent, } \\
\text { extensive, theoretical and } \\
\text { practical knowledge }\end{array}$ & 5.46 & 1.006 & 8 & 5.20 & 1.575 & 7 \\
\hline 17 & $\begin{array}{l}\text { Ability to reflect on own } \\
\text { strengths and weaknesses }\end{array}$ & 5.23 & 1.183 & 20 & 5.18 & 1.545 & 8 \\
\hline 18 & $\begin{array}{l}\text { Participate in on-going } \\
\text { professional development }\end{array}$ & 5.46 & 1.194 & 8* & 5.18 & 1.558 & 8* \\
\hline
\end{tabular}




\begin{tabular}{|c|c|c|c|c|c|c|c|}
\hline & Basic Skills and Competences & Academic & & & Industry & & \\
\hline & & Mean & StDev & Rank & Mean & StDev & Rank \\
\hline 19 & $\begin{array}{l}\text { Possess a sense of basic } \\
\text { curiosity about technology }\end{array}$ & 5.41 & 1.157 & 11 & 5.20 & 1.575 & 7 \\
\hline 20 & Time management skills & 5.39 & 1.156 & 13 & 5.29 & 1.579 & 3 \\
\hline 21 & $\begin{array}{l}\text { Sensitivity to differences in } \\
\text { gender, culture and customs }\end{array}$ & $4.21 * *$ & 1.489 & 24 & 5.20 & 1.575 & 7 \\
\hline 22 & Research skills & 5.44 & 1.089 & 9 & 5.20 & 1.613 & 7 \\
\hline 23 & $\begin{array}{l}\text { Demonstrate practical } \\
\text { knowledge and understanding in at least one } \\
\text { computer } \\
\text { language }\end{array}$ & 5.49 & 1.194 & 7 & 5.12 & 1.608 & 10 \\
\hline 24 & $\begin{array}{l}\text { With respect to the CS } \\
\text { discipline possess theoretical and practical } \\
\text { knowledge in at least one reference discipline }\end{array}$ & 5.43 & 1.081 & 10 & 5.16 & 1.567 & 9 \\
\hline 25 & $\begin{array}{l}\text { Adapt to unfamiliar cultures and operate in a } \\
\text { socially and culturally diverse environment }\end{array}$ & $4.80 * *$ & 1.148 & 23 & 5.20 & 1.637 & 7 \\
\hline 26 & $\begin{array}{l}\text { Knowledge of how a business operate, is } \\
\text { structured or is orientated }\end{array}$ & $4.91 * *$ & 1.151 & 22 & 5.43 & 1.652 & 1 \\
\hline 27 & Understand the profit motive of business & 5.10 & 1.147 & 21 & 5.31 & 1.679 & 2 \\
\hline 28 & $\begin{array}{l}\text { With respect to the CS } \\
\text { discipline possess the } \\
\text { theoretical and theoretical } \\
\text { knowledge of related } \\
\text { disciplines }\end{array}$ & 5.32 & .959 & 15 & 5.25 & 1.647 & 5 \\
\hline 29 & Project management skills & 5.54 & 1.082 & 6 & 5.27 & 1.767 & 4 \\
\hline
\end{tabular}

\subsubsection{Industry}

Analysis of the second-round data for the industry participants (See Table 5) revealed as follows:

1. Two items scored below 5.00 compared to what was obtained in first round where all the items were considered to be very important. The participants are unsure of items ranked 13(Analyze, synthesizes, the various solution) and 14 (Retrieve, evaluate and use relevant information) in their importance in determining the competency of a graduate of HND in CS;

2. The remaining twenty-seven (27) items indicates that, they are very important (mean value of 5.00 and above) but not of major importance or extremely important;

3. Industry participants also rated Knowledge of how a business operate, is structured or is orientated as the most important (mean value of 5.43) the highest on the scale of preference compared to the remaining twenty-six items on the same scale of very important (5.00 and above).

4.2.3 Discussion (Round 2)

A comparison of the analyzed data as shown in Table 5, indicates that, there was significant differences in the views of academic and industry participants. However, academics were consistent in their ranking of five attributes compared with the results of first round. (a) Self-motivation; (b) Be able to participate in continued learning and intellectual development and develop critical, reflective, and creative thinking; (c) With respect to the Computer Science (CS) or Information Technology (IT) discipline be technologically competent (the person is able to use the current technology competently; (d) Embrace change and be obliged to engage in incremental improvement to keep up with the rapid change in technology; (e1) Value the ethics of the information technology profession and (e2) Work as part of a team in a productive and cooperative manner higher on the scale of preference compared to others on the list (Figure 2).

Industry participants ranked five attributes of (a) Knowledge of how a business operate, is structured or is orientated; (b) Understand the profit motive of business; (c) Time management skills; (d) Project management skills; (e1) With respect to the CS discipline possess the theoretical and practical knowledge of related disciplines (e2) Interpersonal skills higher than other items on the list and not too consistent with the results in the first round, a comparison of this results with that obtained in the first round indicate, items (a) and (b) retained their first and second position, while item (c) Time management and item (d) Project management swap position on the scale of preference (Figure 4). 


\section{ATTRIBUTE RANKING \\ (INDUSTRY)ROUND 2}

= Mean $=$ Rank

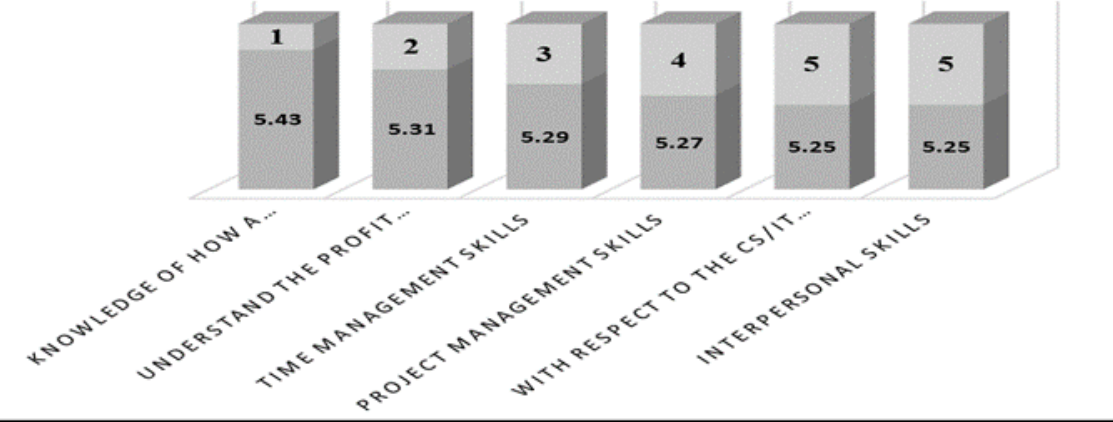

Figure 4: The five highest competency ranking based on the scale of preference by industry (Round 2)

The industry respondents ranked two items, (e1) With respect to the CS discipline possess the theoretical and practical knowledge of related disciplines and (e2) Interpersonal skills on the same scale of preference. For the second round, both groups (academics and industry) have divergent views on each of the items analysed.

\subsection{Result Analysis (Round 3)}

\subsubsection{Academics}

Analysis of the third and final round data for the academic participants (See Table 6) revealed as follows:

1. The three items scored below 5.00 in first and second rounds was retained in the third round. The participants are unsure in the final analysis of their importance in determining the competency of a graduate of HND in CS;

2. The remaining twenty-six (26) items indicates that, they are very important (mean value of 5.00 and above) but not of major importance or extremely important;

3. Compared to the first and second rounds which rate self-motivation the highest on the scale of preference compared to the remaining twenty-five items. Third round analysis rated Be able to participate in continued learning and intellectual development and develop critical, reflective, and creative thinking (mean value of 5.88) the highest

Table 6: Results of Academic and Industry Respondents (Round 3)

\begin{tabular}{|c|c|c|c|c|c|c|c|}
\hline & Basic Skills and Competences & Academic & & & Industry & & \\
\hline & & Mean & StDev & Rank & Mean & StDev & Rank \\
\hline 1 & Self-motivation & 5.69 & 1.433 & 3 & 5.10 & 1.526 & 11 \\
\hline 2 & $\begin{array}{l}\text { Retrieve, evaluate and use } \\
\text { relevant information }\end{array}$ & 5.63 & 1.129 & 4 & $4.96 * *$ & 1.483 & 14 \\
\hline 3 & $\begin{array}{l}\text { Be able to participate in } \\
\text { continued learning and } \\
\text { intellectual development and } \\
\text { develop critical, reflective, and creative } \\
\text { thinking. }\end{array}$ & 5.88 & 1.125 & 1 & 5.18 & 1.506 & 8 \\
\hline 4 & $\begin{array}{l}\text { Analyze, synthesizes the } \\
\text { various solutions }\end{array}$ & 5.31 & .967 & 17 & $4.98 * *$ & 1.556 & 13 \\
\hline 5 & $\begin{array}{l}\text { Confidence about their ability to learn } \\
\text { independently }\end{array}$ & 5.50 & 1.324 & 10 & 5.06 & 1.502 & 12 \\
\hline 6 & $\begin{array}{l}\text { Consider the quality of the } \\
\text { solution and its timeliness }\end{array}$ & 5.28 & 1.124 & 22 & 5.16 & 1.567 & 9 \\
\hline 7 & $\begin{array}{l}\text { Embrace change and be obliged to engage in } \\
\text { incremental } \\
\text { improvement to keep up with } \\
\text { the rapid change in technology }\end{array}$ & 5.71 & 1.244 & 2 & 5.20 & 1.536 & 7 \\
\hline 8 & $\begin{array}{l}\text { Work as part of a team in a } \\
\text { productive and cooperative } \\
\text { manner. }\end{array}$ & 5.62 & .988 & 5 & 5.10 & 1.526 & 11 \\
\hline
\end{tabular}




\begin{tabular}{|c|c|c|c|c|c|c|c|}
\hline & Basic Skills and Competences & Academic & & & Industry & & \\
\hline & & Mean & StDev & Rank & Mean & StDev & Rank \\
\hline 9 & $\begin{array}{l}\text { With respect to the Computer Science (CS) or } \\
\text { Information Technology (IT) discipline be } \\
\text { technologically competent (the person is able } \\
\text { to use the current technology competently) }\end{array}$ & 5.71 & 1.169 & 2 & 5.24 & 1.582 & 6 \\
\hline 10 & $\begin{array}{l}\text { Value the ethics of the } \\
\text { Information Technology } \\
\text { profession }\end{array}$ & 5.54 & 1.127 & 7 & 5.10 & 1.578 & 11 \\
\hline 11 & Oral communication skills & 5.52 & 1.045 & 9 & 5.20 & 1.613 & 7 \\
\hline 12 & $\begin{array}{l}\text { Define problems in a } \\
\text { systematic way }\end{array}$ & 5.38 & 1.057 & 13 & 5.24 & 1.544 & 6 \\
\hline 13 & Interpersonal skills & 5.27 & 1.139 & 19 & 5.25 & 1.547 & 5 \\
\hline 14 & Work independently & 5.35 & 1.099 & 15 & 5.16 & 1.567 & 9 \\
\hline 15 & Written communication skills & 5.26 & 1.137 & 20 & 5.16 & 1.515 & 9 \\
\hline 16 & $\begin{array}{l}\text { With respect to the CS } \\
\text { discipline possess coherent, } \\
\text { extensive, theoretical and } \\
\text { practical knowledge }\end{array}$ & 5.44 & 1.153 & 11 & 5.20 & 1.575 & 7 \\
\hline 17 & $\begin{array}{l}\text { Ability to reflect on own } \\
\text { strengths and weaknesses }\end{array}$ & 5.20 & 1.140 & 21 & 5.18 & 1.545 & 8 \\
\hline 18 & $\begin{array}{l}\text { Participate in on-going } \\
\text { professional development }\end{array}$ & 5.42 & 1.177 & 12 & 5.18 & 1.558 & 8 \\
\hline 19 & $\begin{array}{l}\text { Possess a sense of basic } \\
\text { curiosity about technology }\end{array}$ & 5.38 & 1.057 & 13 & 5.20 & 1.575 & 7 \\
\hline 20 & Time management skills & 5.33 & 1.096 & 16 & 5.29 & 1.579 & 3 \\
\hline 21 & $\begin{array}{l}\text { Sensitivity to differences in } \\
\text { gender, culture and customs }\end{array}$ & $4.28 * *$ & 1.357 & 25 & 5.20 & 1.575 & 7 \\
\hline 22 & Research skills & 5.44 & 1.099 & 11 & 5.20 & 1.613 & 7 \\
\hline 23 & $\begin{array}{l}\text { Demonstrate practical } \\
\text { knowledge and understanding in at least one } \\
\text { computer } \\
\text { language }\end{array}$ & 5.58 & 1.151 & 6 & 5.12 & 1.608 & 10 \\
\hline 24 & $\begin{array}{l}\text { With respect to the CS } \\
\text { discipline possess theoretical } \\
\text { and practical knowledge in at } \\
\text { least one reference discipline }\end{array}$ & 5.37 & 1.146 & 14 & 5.16 & 1.567 & 9 \\
\hline 25 & $\begin{array}{l}\text { Adapt to unfamiliar cultures } \\
\text { and operate in a socially and } \\
\text { culturally diverse environment }\end{array}$ & $4.71 * *$ & 1.203 & 24 & 5.20 & 1.637 & 7 \\
\hline 26 & $\begin{array}{l}\text { Knowledge of how a business } \\
\text { operate, is structured or is } \\
\text { orientated }\end{array}$ & $4.90^{* *}$ & 1.109 & 23 & 5.43 & 1.652 & 1 \\
\hline 27 & Understand the profit motive of business & 5.14 & 1.114 & 22 & 5.31 & 1.679 & 2 \\
\hline 28 & $\begin{array}{l}\text { With respect to the CS } \\
\text { discipline possess the } \\
\text { theoretical and theoretical } \\
\text { knowledge of related } \\
\text { disciplines }\end{array}$ & 5.31 & .997 & 17 & 5.25 & 1.647 & 5 \\
\hline 29 & Project management skills & 5.53 & 1.082 & 8 & 5.27 & 1.767 & 4 \\
\hline
\end{tabular}

\subsubsection{Industry}

The third-round data analysis for the industry participants (See Table 5) revealed as follows:

1. Two items which scored below 5.00 in the second round was retained for the third and final round. The participants are unsure of items ranked 13 and 14 in their importance in determining the competency of a graduate of HND in CS;

2. The remaining twenty-seven (27) items indicates that, they are very important (mean value of 5.00 and above) but not of major importance or extremely important; 
3. Industry participants in the final analysis rated Knowledge of how a business operate, is structured or is orientated as the most important (mean value of 5.43) the highest on the scale of preference compared to the remaining twenty-six items on the same scale of very important (5.00 and above). This is consistent with their views in first and second round.

\subsubsection{Discussion (Round 3)}

A comparison of the analysed data as shown in Table 6, indicates that, significant differences in the views of academic and industry participants was retained for the final analysis. While academics ranked five attributes (a) Be able to participate in continued learning and intellectual development and develop critical, reflective, and creative thinking; (b) Embrace change and be obliged to engage in incremental improvement to keep up with the rapid change in technology; (c) Self-motivation; (d) Retrieve, evaluate and use relevant information; (e) Work as part of a team in a productive and cooperative manner higher on the scale of preference compared to others on the list.

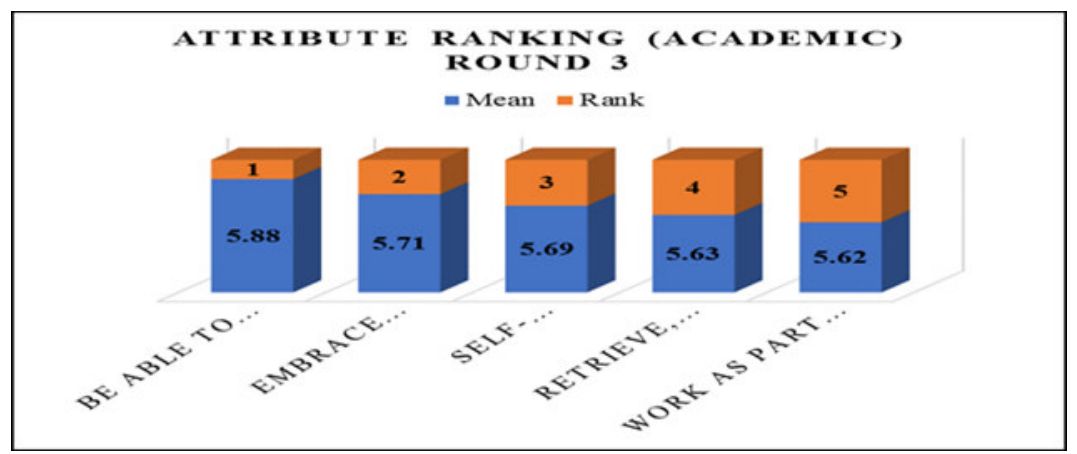

Figure 5: The five highest competency ranking based on the scale of preference by academic (Round 3)

The industry participants in their final view considered the following five attributes of (a) Knowledge of how a business operate, is structured or is orientated; (b) Understand the profit motive of business; (c) Time management skills; (d) Project management skills; (e1) With respect to the CS discipline possess the theoretical and practical knowledge of related disciplines (e2) Interpersonal skills higher than other items on the list and which is consistent with the results obtained in the second round (Figure 4).

\subsection{Matrix of Generic Attributes and HND Curriculum}

Table 5 present a matrix of the skills and competences attributes in relation to the existing curriculum. Attributes considered to have been stated in the learning outcome for each course are indicated using $(\sqrt{ })$ while those found not have been stated in learning outcome for each course are indicated using (x). Table 5 shows that, attributes with serial numbers 1 to 20,22 and 25 were considered to be present in the learning outcome of the courses provided in the curriculum. Equally, 95\% of attributes with serial numbers 24, 26, 27 and 29 were considered present in the learning outcome of courses in the curriculum.

Attributes with serial numbers 21 ("Sensitivity to difference in gender, culture and customs") and 25 ("Adapt to unfamiliar cultures and operates in a socially and culturally diverse environment") were completely absent in the curriculum currently offered. While academic participants do not consider these two attributes important on the scale of preference, industrial participants were of the opinion that, the two attributes should the considered important in other to improve the employability of an HND CS graduates since the country is cultural and socially diverse (more than 250 ethnic/cultural groups) and graduates of various higher institutions are expected to work in any part of the country where languages and culture are a serious impediments to employment.

Table 5: Matrix of Attributes and NBTE HND Curriculum

\begin{tabular}{|c|c|c|c|c|c|c|c|c|c|c|c|c|c|c|c|c|c|c|c|c|c|c|c|c|c|c|c|c|c|}
\hline $\begin{array}{l}\mathbf{S} / \\
\mathbf{N}\end{array}$ & $\begin{array}{l}\text { COURSE } \\
\text { CODE \& } \\
\text { TITLE } \\
\end{array}$ & $\mathbf{1}$ & 2 & 3 & 4 & 5 & 57 & 8 & 9 & $\begin{array}{l}1 \\
0\end{array}$ & $\begin{array}{l}1 \\
1\end{array}$ & $\begin{array}{l}1 \\
2\end{array}$ & $\begin{array}{l}1 \\
3\end{array}$ & $\begin{array}{l}1 \\
4\end{array}$ & $\begin{array}{l}1 \\
5\end{array}$ & $\begin{array}{l}1 \\
6\end{array}$ & 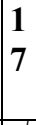 & $\begin{array}{l}1 \\
8\end{array}$ & $\begin{array}{l}1 \\
9\end{array}$ & $\begin{array}{l}2 \\
0\end{array}$ & $\begin{array}{l}2 \\
1\end{array}$ & $\begin{array}{l}2 \\
2\end{array}$ & $\begin{array}{l}2 \\
3\end{array}$ & $\begin{array}{l}2 \\
4\end{array}$ & $\begin{array}{l}2 \\
5\end{array}$ & $\begin{array}{l}2 \\
6\end{array}$ & $\begin{array}{l}2 \\
7\end{array}$ & $\begin{array}{l}2 \\
8\end{array}$ & $\begin{array}{l}2 \\
9\end{array}$ \\
\hline 1 & $\begin{array}{l}\text { COM311- } \\
\text { Operating } \\
\text { System I } \\
\end{array}$ & $\sqrt{1}$ & $\sqrt{1}$ & $\sqrt{1}$ & $\sqrt{1}$ & $\sqrt{1}$ & $\sqrt{1}$ & $\sqrt{ }$ & $\sqrt{ }$ & $\sqrt{ }$ & $\sqrt{ }$ & $\sqrt{ }$ & $\sqrt{ }$ & $\sqrt{ }$ & $\sqrt{ }$ & $\sqrt{ }$ & $\sqrt{ }$ & $\sqrt{ }$ & $\sqrt{ }$ & $\sqrt{ }$ & $\mathrm{x}$ & $\sqrt{ }$ & $\sqrt{ }$ & $\mathrm{x}$ & $\mathrm{X}$ & $\mathrm{X}$ & $\mathrm{x}$ & $\mathrm{x}$ & $\mathrm{X}$ \\
\hline 2 & $\begin{array}{l}\text { COM122- } \\
\text { Database } \\
\text { Design I }\end{array}$ & $\sqrt{1}$ & $\sqrt{1}$ & $\sqrt{1}$ & $\sqrt{1}$ & $\sqrt{1}$ & $\sqrt{1}$ & 1 & $\sqrt{ }$ & $\sqrt{ }$ & $\sqrt{ }$ & $\sqrt{ }$ & $\sqrt{ }$ & $\sqrt{ }$ & $\sqrt{ }$ & $\sqrt{ }$ & $\sqrt{ }$ & $\sqrt{ }$ & $\sqrt{ }$ & $\sqrt{ }$ & $x$ & $\sqrt{ }$ & $\sqrt{ }$ & $\mathrm{x}$ & $\mathrm{X}$ & $\mathrm{X}$ & $\mathrm{x}$ & $\mathrm{x}$ & $\mathrm{X}$ \\
\hline
\end{tabular}




\begin{tabular}{|c|c|c|c|c|c|c|c|c|c|c|c|c|c|c|c|c|c|c|c|c|c|c|c|c|c|c|c|c|c|c|}
\hline $\begin{array}{l}\mathbf{S} / \\
\mathbf{N}\end{array}$ & $\begin{array}{l}\text { COURSE } \\
\text { CODE \& } \\
\text { TITLE } \\
\end{array}$ & 1 & 2 & 3 & 4 & 5 & 67 & 7 & $\begin{array}{ll}8 & 9\end{array}$ & $\begin{array}{l}1 \\
0\end{array}$ & $\begin{array}{l}1 \\
1\end{array}$ & $\begin{array}{l}1 \\
2\end{array}$ & $\begin{array}{l}1 \\
3\end{array}$ & $\begin{array}{l}1 \\
4\end{array}$ & $\begin{array}{l}1 \\
5\end{array}$ & $\begin{array}{l}1 \\
6\end{array}$ & $\begin{array}{l}1 \\
7\end{array}$ & $\begin{array}{l}1 \\
8\end{array}$ & $\begin{array}{l}1 \\
9\end{array}$ & & $\begin{array}{l}2 \\
0\end{array}$ & $\begin{array}{l}2 \\
1\end{array}$ & $\begin{array}{l}2 \\
2\end{array}$ & $\begin{array}{l}2 \\
3\end{array}$ & $\begin{array}{l}2 \\
4\end{array}$ & $\begin{array}{l}2 \\
5\end{array}$ & $\begin{array}{l}2 \\
6\end{array}$ & $\begin{array}{l}2 \\
7\end{array}$ & $\begin{array}{l}2 \\
8\end{array}$ & $\begin{array}{l}2 \\
9\end{array}$ \\
\hline 3 & $\begin{array}{l}\text { COM313- } \\
\text { Computer } \\
\text { Programmi-ng } \\
\text { Using } \\
\text { C++ } \\
\end{array}$ & $\sqrt{ }$ & $\sqrt{ }$ & $\sqrt{ }$ & $\sqrt{ }$ & $\sqrt{ }$ & $\sqrt{1}$ & $\sqrt{1}$ & $\sqrt{1}$ & $\sqrt{ }$ & $\sqrt{ }$ & $\sqrt{ }$ & $\sqrt{ }$ & $\sqrt{ }$ & $\sqrt{ }$ & $\sqrt{ }$ & $\sqrt{ }$ & $\sqrt{ }$ & & $\sqrt{ }$ & $\sqrt{ }$ & $\mathrm{X}$ & $\sqrt{ }$ & $\sqrt{ }$ & $\mathrm{x}$ & $\mathrm{x}$ & $\mathrm{X}$ & $\mathrm{x}$ & $\mathrm{x}$ & $\mathrm{x}$ \\
\hline 4 & $\begin{array}{l}\text { COM314- } \\
\text { Computer } \\
\text { Architecture } \\
\end{array}$ & $\sqrt{ }$ & $\sqrt{1}$ & $\sqrt{1}$ & $\sqrt{1}$ & $\sqrt{1}$ & $\sqrt{1}$ & $\sqrt{1}$ & $\sqrt{11}$ & $\sqrt{1}$ & $\sqrt{ }$ & $\sqrt{ }$ & $\sqrt{ }$ & $\sqrt{ }$ & $\sqrt{ }$ & $\sqrt{ }$ & $\sqrt{ }$ & $\sqrt{ }$ & & $\sqrt{ }$ & $\sqrt{ }$ & $\mathrm{X}$ & $\sqrt{ }$ & $\sqrt{ }$ & $\mathrm{x}$ & $\mathrm{x}$ & $\mathrm{x}$ & $\mathrm{x}$ & $\mathrm{x}$ & $\mathrm{x}$ \\
\hline 5 & $\begin{array}{l}\text { COM315- } \\
\text { Numerical } \\
\text { Methods }\end{array}$ & $\sqrt{ }$ & $\sqrt{1}$ & $\sqrt{1}$ & $\sqrt{ }$ & $\sqrt{1}$ & $\sqrt{ }$ & $\sqrt{1}$ & $\sqrt{11}$ & $\sqrt{ }$ & $\sqrt{ }$ & $\sqrt{ }$ & $\sqrt{ }$ & $\sqrt{ }$ & $\sqrt{ }$ & $\sqrt{ }$ & $\sqrt{ }$ & $\sqrt{ }$ & & $\sqrt{ }$ & $\sqrt{ }$ & $\mathrm{x}$ & $\sqrt{ }$ & $\sqrt{ }$ & $\mathrm{x}$ & $\mathrm{x}$ & $\mathrm{x}$ & $\mathrm{x}$ & $\mathrm{x}$ & $\mathrm{x}$ \\
\hline 6 & \begin{tabular}{|l|} 
STA314- \\
Operations \\
Research I \\
\end{tabular} & $\sqrt{1}$ & $\sqrt{ }$ & $\sqrt{1}$ & $\sqrt{ }$ & $\sqrt{1}$ & $\sqrt{1}$ & $\sqrt{1}$ & $\sqrt{1}$ & $\sqrt{ }$ & $\sqrt{ }$ & $\sqrt{ }$ & $\sqrt{ }$ & $\sqrt{ }$ & $\sqrt{ }$ & $\sqrt{ }$ & $\sqrt{ }$ & $\sqrt{ }$ & & $\sqrt{ }$ & $\sqrt{ }$ & $\mathrm{X}$ & $\sqrt{ }$ & $\sqrt{ }$ & $\mathrm{x}$ & $\mathrm{x}$ & $\mathrm{x}$ & $\mathrm{x}$ & $\sqrt{ }$ & $\mathrm{x}$ \\
\hline 7 & $\begin{array}{l}\text { STA311- } \\
\text { Statistics } \\
\text { Theory I } \\
\end{array}$ & $\sqrt{ }$ & $\sqrt{10}$ & $\sqrt{1}$ & $\sqrt{1}$ & $\sqrt{1}$ & $\sqrt{1}$ & $\sqrt{1}$ & $\sqrt{11}$ & $\sqrt{1}$ & $\sqrt{ }$ & $\sqrt{ }$ & $\sqrt{ }$ & $\sqrt{ }$ & $\sqrt{ }$ & $\sqrt{ }$ & $\sqrt{ }$ & $\mathrm{X}$ & & $\sqrt{ }$ & $\sqrt{ }$ & $\mathrm{X}$ & $\sqrt{ }$ & $\sqrt{ }$ & $\mathrm{x}$ & $\mathrm{x}$ & $\mathrm{x}$ & $\mathrm{x}$ & $\sqrt{ }$ & $\mathrm{x}$ \\
\hline 8 & \begin{tabular}{|l|} 
GNS315- \\
Business \\
Communication \\
s I \\
\end{tabular} & $\sqrt{1}$ & $\sqrt{10}$ & $\sqrt{1}$ & $\sqrt{1}$ & $\sqrt{1}$ & $\sqrt{ }$ & $\sqrt{ }$ & $\sqrt{11}$ & $\sqrt{ }$ & $\sqrt{ }$ & $\sqrt{ }$ & $\sqrt{ }$ & $\sqrt{ }$ & $\sqrt{ }$ & $\sqrt{ }$ & $\sqrt{ }$ & $\bar{X}$ & & $\sqrt{ }$ & $\sqrt{ }$ & $\mathrm{x}$ & $\sqrt{ }$ & $\sqrt{ }$ & $\mathrm{x}$ & $x$ & $\sqrt{ }$ & $x$ & $\sqrt{ }$ & $\mathrm{x}$ \\
\hline 9 & $\begin{array}{l}\text { COM122- } \\
\text { Operating } \\
\text { System II } \\
\end{array}$ & $\sqrt{1}$ & $\sqrt{ }$ & $\sqrt{1}$ & $\sqrt{ }$ & $\sqrt{1}$ & $\sqrt{ }$ & $\sqrt{ }$ & $\sqrt{1}$ & $\sqrt{ }$ & $\sqrt{ }$ & $\sqrt{ }$ & $\sqrt{ }$ & $\sqrt{ }$ & $\sqrt{ }$ & $\sqrt{ }$ & $\sqrt{ }$ & $\sqrt{ }$ & & $\sqrt{ }$ & $\sqrt{ }$ & $\mathrm{X}$ & $\sqrt{ }$ & $\sqrt{ }$ & $\mathrm{x}$ & $\mathrm{x}$ & $\mathrm{X}$ & $\mathrm{x}$ & $\mathrm{x}$ & $\mathrm{x}$ \\
\hline 10 & $\begin{array}{l}\text { COM322- } \\
\text { Database } \\
\text { Design II } \\
\end{array}$ & $\sqrt{ }$ & $\sqrt{ }$ & $\sqrt{1}$ & $\sqrt{ }$ & $\sqrt{ }$ & $\sqrt{1}$ & $\sqrt{ }$ & $\sqrt{1}$ & $\sqrt{ }$ & $\sqrt{ }$ & $\sqrt{ }$ & $\sqrt{ }$ & $\sqrt{ }$ & $\sqrt{ }$ & $\sqrt{ }$ & $\sqrt{ }$ & $\sqrt{ }$ & & $\sqrt{ }$ & $\sqrt{ }$ & $\mathrm{X}$ & $\sqrt{ }$ & $\sqrt{ }$ & $\mathrm{x}$ & $\mathrm{x}$ & $\mathrm{X}$ & $\mathrm{x}$ & $\mathrm{x}$ & $\mathrm{x}$ \\
\hline 11 & $\begin{array}{l}\text { COM122- } \\
\text { Assembly } \\
\text { Language }\end{array}$ & $\sqrt{ }$ & $\sqrt{1}$ & $\sqrt{1}$ & $\sqrt{1}$ & $\sqrt{1}$ & $\sqrt{1}$ & $\sqrt{ }$ & $\sqrt{11}$ & $\sqrt{ }$ & $\sqrt{ }$ & $\sqrt{ }$ & $\sqrt{ }$ & $\sqrt{ }$ & $\sqrt{ }$ & $\sqrt{ }$ & $\sqrt{ }$ & $\sqrt{ }$ & & $\sqrt{ }$ & $\sqrt{ }$ & $\mathrm{X}$ & $\sqrt{ }$ & $\sqrt{ }$ & $\mathrm{x}$ & $\mathrm{x}$ & $\mathrm{X}$ & $\mathrm{x}$ & $\mathrm{x}$ & $\mathrm{x}$ \\
\hline 12 & \begin{tabular}{|l|} 
COM324- \\
Intro. to \\
Software \\
Engineering
\end{tabular} & $\sqrt{1}$ & $\sqrt{ }$ & $\sqrt{ }$ & $\sqrt{ }$ & $\sqrt{1}$ & $\sqrt{1}$ & $\sqrt{1}$ & $\sqrt{1}$ & $\sqrt{ }$ & $\sqrt{ }$ & $\sqrt{ }$ & $\sqrt{ }$ & $\sqrt{ }$ & $\sqrt{ }$ & $\sqrt{ }$ & $\sqrt{ }$ & $\sqrt{ }$ & & $\sqrt{ }$ & $\sqrt{ }$ & $\mathrm{X}$ & $\sqrt{ }$ & $\sqrt{ }$ & $x$ & $x$ & $\mathrm{X}$ & $x$ & $\mathrm{x}$ & $\mathrm{x}$ \\
\hline 13 & $\begin{array}{l}\text { COM325- } \\
\text { Advanced Web } \\
\text { Technology }\end{array}$ & $\sqrt{1}$ & $\sqrt{1}$ & $\sqrt{ }$ & $\sqrt{ }$ & $\sqrt{1}$ & $\sqrt{1}$ & $\sqrt{ }$ & $\sqrt{ } 1$ & $\sqrt{ }$ & $\sqrt{ }$ & $\sqrt{ }$ & $\sqrt{ }$ & $\sqrt{ }$ & $\sqrt{ }$ & $\sqrt{ }$ & $\sqrt{ }$ & $\sqrt{ }$ & & $\sqrt{ }$ & $\sqrt{ }$ & $\mathrm{X}$ & $\sqrt{ }$ & $\sqrt{ }$ & $x$ & $\mathrm{x}$ & $\mathrm{x}$ & $\mathrm{x}$ & $\mathrm{x}$ & $\mathrm{x}$ \\
\hline 14 & $\begin{array}{l}\text { COM326- Intro. } \\
\text { To } \\
\text { Human- } \\
\text { Computer } \\
\text { Interface. (HCI) }\end{array}$ & $\sqrt{1}$ & $\sqrt{1}$ & $\sqrt{1}$ & $\sqrt{1}$ & $\sqrt{1}$ & $\sqrt{1}$ & $\sqrt{1}$ & $\sqrt{11}$ & $\sqrt{ }$ & $\sqrt{ }$ & $\sqrt{ }$ & $\sqrt{ }$ & $\sqrt{ }$ & $\sqrt{ }$ & $\sqrt{ }$ & $\sqrt{ }$ & $\sqrt{ }$ & & $\sqrt{ }$ & $\sqrt{ }$ & $\mathrm{X}$ & $\sqrt{ }$ & $\sqrt{ }$ & $\mathrm{x}$ & $\mathrm{x}$ & $\mathrm{x}$ & $\mathrm{x}$ & $\mathrm{x}$ & $\mathrm{x}$ \\
\hline 15 & $\begin{array}{l}\text { STA321- } \\
\text { Statistical } \\
\text { Theory II } \\
\end{array}$ & $\sqrt{ }$ & $\sqrt{ }$ & $\sqrt{ }$ & $\sqrt{2}$ & $\sqrt{1}$ & $\sqrt{1}$ & $\sqrt{ }$ & $\sqrt{ } 1$ & $\sqrt{ }$ & $\sqrt{ }$ & $\sqrt{ }$ & $\sqrt{ }$ & $\sqrt{ }$ & $\sqrt{ }$ & $\sqrt{ }$ & $\sqrt{ }$ & $\mathrm{x}$ & & $\mathrm{x}$ & $\sqrt{ }$ & $\mathrm{x}$ & $\sqrt{ }$ & $\sqrt{ }$ & $\mathrm{x}$ & $\mathrm{x}$ & $\mathrm{x}$ & $\mathrm{x}$ & $\sqrt{ }$ & $\mathrm{x}$ \\
\hline 16 & \begin{tabular}{|l|} 
GNS302- \\
Communication \\
$\mathrm{s}$ in \\
English II
\end{tabular} & $\sqrt{1}$ & $\sqrt{1}$ & $\sqrt{1}$ & $\sqrt{1}$ & $\sqrt{1}$ & $\sqrt{1}$ & $\sqrt{1}$ & $\sqrt{\sqrt{1}} \mathrm{x}$ & $\sqrt{ }$ & $\sqrt{ }$ & $\sqrt{ }$ & $\sqrt{ }$ & $\sqrt{ }$ & $\sqrt{ }$ & $\sqrt{ }$ & $\sqrt{ }$ & $\mathrm{x}$ & & $\mathrm{X}$ & $\sqrt{ }$ & $\mathrm{x}$ & $\sqrt{ }$ & $\mathrm{x}$ & $\mathrm{x}$ & $\mathrm{x}$ & $\mathrm{x}$ & $x$ & $\sqrt{ }$ & $\mathrm{x}$ \\
\hline 17 & $\begin{array}{l}\text { EED323- } \\
\text { Entrepreneu- } \\
\text { rship } \\
\text { Developme-nt II }\end{array}$ & $\sqrt{ }$ & $\sqrt{ }$ & $\sqrt{ }$ & $\sqrt{ }$ & $\sqrt{1}$ & $\sqrt{ }$ & $\sqrt{ }$ & $\sqrt{ } x$ & $\sqrt{ }$ & $\sqrt{ }$ & $\sqrt{ }$ & $\sqrt{ }$ & $\sqrt{ }$ & $\sqrt{ }$ & $\sqrt{ }$ & $\sqrt{ }$ & $\mathrm{x}$ & & $\mathrm{X}$ & $\sqrt{ }$ & $\mathrm{X}$ & $\sqrt{ }$ & $\mathrm{X}$ & $\sqrt{ }$ & $\mathrm{X}$ & $\sqrt{ }$ & $\sqrt{ }$ & $\sqrt{ }$ & $\sqrt{ }$ \\
\hline
\end{tabular}




\begin{tabular}{|c|c|c|c|c|c|c|c|c|c|c|c|c|c|c|c|c|c|c|c|c|c|c|c|c|c|c|c|c|c|}
\hline $\begin{array}{l}\mathbf{S} / \\
\mathbf{N}\end{array}$ & $\begin{array}{l}\text { COURSE } \\
\text { CODE \& } \\
\text { TITLE } \\
\end{array}$ & 1 & 2 & \begin{tabular}{|l|}
3 \\
\end{tabular} & 4 & 5 & \begin{tabular}{l|l}
6 & 7
\end{tabular} & 8 & 9 & & $\begin{array}{l}1 \\
1\end{array}$ & $\begin{array}{l}1 \\
2\end{array}$ & $\begin{array}{l}1 \\
3\end{array}$ & $\begin{array}{l}1 \\
4\end{array}$ & $\begin{array}{l}1 \\
5\end{array}$ & $\begin{array}{l}1 \\
6\end{array}$ & $\begin{array}{l}1 \\
7\end{array}$ & $\begin{array}{l}1 \\
8\end{array}$ & $\begin{array}{l}1 \\
9\end{array}$ & $\begin{array}{l}2 \\
0\end{array}$ & $\begin{array}{l}2 \\
1\end{array}$ & 2 & $\begin{array}{l}2 \\
3\end{array}$ & $\begin{array}{l}2 \\
4\end{array}$ & $\begin{array}{l}2 \\
5\end{array}$ & $\begin{array}{l}2 \\
6\end{array}$ & $\begin{array}{l}2 \\
7\end{array}$ & $\begin{array}{l}2 \\
8\end{array}$ & $\begin{array}{l}2 \\
9\end{array}$ \\
\hline 18 & $\begin{array}{l}\text { COM411- } \\
\text { Managt. } \\
\text { Information } \\
\text { Systems } \\
\end{array}$ & $\sqrt{ }$ & $\sqrt{1}$ & $\sqrt{1}$ & $\sqrt{ }$ & $\sqrt{1}$ & $\sqrt{ }$ & 17 & $\sqrt{ }$ & $\sqrt{ }$ & $\sqrt{ }$ & $\sqrt{ }$ & $\sqrt{ }$ & $\sqrt{ }$ & $\sqrt{ }$ & $\sqrt{ }$ & $\sqrt{ }$ & $\sqrt{ }$ & $\sqrt{ }$ & $\sqrt{ }$ & $\mathrm{x}$ & $\sqrt{ }$ & $\sqrt{ }$ & $\mathrm{x}$ & $\mathrm{X}$ & $\mathrm{x}$ & $x$ & $\mathrm{X}$ & $\mathrm{x}$ \\
\hline 19 & $\begin{array}{l}\text { COM412- } \\
\text { Computer } \\
\text { Programm-ing } \\
\text { (OO } \\
\text { PASCAL) } \\
\end{array}$ & $\sqrt{ }$ & $\sqrt{1}$ & $\sqrt{ }$ & $\sqrt{ }$ & $\sqrt{1}$ & $\sqrt{1}$ & $\pi v$ & $\sqrt{ }$ & $\sqrt{ }$ & $\sqrt{ }$ & $\sqrt{ }$ & $\sqrt{ }$ & $\sqrt{ }$ & $\sqrt{ }$ & $\sqrt{ }$ & $\sqrt{ }$ & $\sqrt{ }$ & $\sqrt{ }$ & $\sqrt{ }$ & $\mathrm{x}$ & $\sqrt{ }$ & $\sqrt{ }$ & $\mathrm{x}$ & $\mathrm{X}$ & $\mathrm{x}$ & $\mathrm{x}$ & $\mathrm{X}$ & $\mathrm{x}$ \\
\hline 20 & $\begin{array}{l}\text { COM413- } \\
\text { Project } \\
\text { Manageme-nt } \\
\end{array}$ & $\sqrt{ }$ & $\sqrt{1}$ & $\sqrt{1}$ & $\sqrt{ }$ & $\sqrt{1}$ & $\sqrt{ }$ & 17 & $\sqrt{ }$ & $\sqrt{ }$ & $\sqrt{ }$ & $\sqrt{ }$ & $\sqrt{ }$ & $\sqrt{ }$ & $\sqrt{ }$ & $\sqrt{ }$ & $\sqrt{ }$ & $\sqrt{ }$ & $\sqrt{ }$ & $\sqrt{ }$ & $\mathrm{x}$ & $\sqrt{ }$ & $\sqrt{ }$ & $\mathrm{x}$ & $\mathrm{X}$ & $\mathrm{x}$ & $\mathrm{x}$ & $\mathrm{X}$ & $\sqrt{ }$ \\
\hline 21 & $\begin{array}{l}\text { COM414- } \\
\text { Compiler } \\
\text { Construct-ion }\end{array}$ & $\sqrt{ }$ & $\sqrt{1}$ & $\sqrt{1}$ & $\sqrt{1}$ & $\sqrt{1}$ & $\sqrt{1}$ & 17 & $\sqrt{ }$ & $\sqrt{ }$ & $\sqrt{ }$ & $\sqrt{ }$ & $\sqrt{ }$ & $\sqrt{ }$ & $\sqrt{ }$ & $\sqrt{ }$ & $\sqrt{ }$ & $\sqrt{ }$ & $\sqrt{ }$ & $\sqrt{ }$ & $\mathrm{x}$ & $\sqrt{ }$ & $\sqrt{ }$ & $\mathrm{x}$ & $\mathrm{X}$ & $\mathrm{x}$ & $\mathrm{x}$ & $\mathrm{X}$ & $\bar{x}$ \\
\hline 22 & $\begin{array}{l}\text { COM415 - Data } \\
\text { Communication } \\
\text { and } \\
\text { Networks }\end{array}$ & $\sqrt{ }$ & $\sqrt{1}$ & $\sqrt{1}$ & $\sqrt{1}$ & $\sqrt{1}$ & $\sqrt{ } \sqrt{1}$ & 17 & $\sqrt{1}$ & $\sqrt{ }$ & $\sqrt{ }$ & $\sqrt{ }$ & $\sqrt{ }$ & $\sqrt{ }$ & $\sqrt{ }$ & $\sqrt{ }$ & $\sqrt{ }$ & $\sqrt{ }$ & $\sqrt{ }$ & $\sqrt{ }$ & $\mathrm{x}$ & $\sqrt{ }$ & $\sqrt{ }$ & $\mathrm{x}$ & $\mathrm{X}$ & $\mathrm{x}$ & $x$ & $\mathrm{X}$ & $\mathrm{x}$ \\
\hline 23 & $\begin{array}{l}\text { COM416- } \\
\text { Multimedia }\end{array}$ & $\sqrt{ }$ & $\sqrt{1}$ & $\sqrt{1}$ & $\sqrt{1}$ & $\sqrt{1}$ & $\sqrt{1}$ & $\sqrt{ }$ & $\sqrt{1}$ & $\sqrt{ }$ & $\sqrt{ }$ & $\sqrt{ }$ & $\sqrt{ }$ & $\sqrt{ }$ & $\sqrt{ }$ & $\sqrt{ }$ & $\sqrt{ }$ & $\sqrt{ }$ & $\sqrt{ }$ & $\sqrt{ }$ & $x$ & $\sqrt{ }$ & $\sqrt{ }$ & $\mathrm{x}$ & $\mathrm{X}$ & $\mathrm{x}$ & $x$ & $\mathrm{X}$ & $\mathrm{x}$ \\
\hline 24 & $\begin{array}{l}\text { COM417- } \\
\text { Mobile } \\
\text { Computing }\end{array}$ & $\sqrt{ }$ & $\sqrt{1}$ & $\sqrt{1}$ & $\sqrt{1}$ & $\sqrt{1}$ & $\sqrt{ } \sqrt{1}$ & $\sqrt{ }$ & $\sqrt{ }$ & $\sqrt{ }$ & $\sqrt{ }$ & $\sqrt{ }$ & $\sqrt{ }$ & $\sqrt{ }$ & $\sqrt{ }$ & $\sqrt{ }$ & $\sqrt{ }$ & $\sqrt{ }$ & $\sqrt{ }$ & $\sqrt{ }$ & $\mathrm{x}$ & $\sqrt{ }$ & $\sqrt{ }$ & $\mathrm{x}$ & $\mathrm{X}$ & $\mathrm{x}$ & $\mathrm{x}$ & $\mathrm{X}$ & $\mathrm{x}$ \\
\hline 25 & $\begin{array}{l}\text { STA411- } \\
\text { Operations } \\
\text { Research II } \\
\end{array}$ & $\sqrt{ }$ & $\sqrt{1}$ & $\sqrt{1}$ & $\sqrt{1}$ & $\sqrt{1}$ & $\sqrt{1}$ & 17 & $\sqrt{ }$ & $\sqrt{ }$ & $\sqrt{ }$ & $\sqrt{ }$ & $\sqrt{ }$ & $\sqrt{ }$ & $\sqrt{ }$ & $\sqrt{ }$ & $\sqrt{ }$ & $\sqrt{ }$ & $\sqrt{ }$ & $\sqrt{ }$ & $\mathrm{x}$ & $\sqrt{ }$ & $\sqrt{ }$ & $\mathrm{x}$ & $\mathrm{x}$ & $\mathrm{x}$ & $\mathrm{x}$ & $\sqrt{ }$ & $\bar{x}$ \\
\hline 26 & $\begin{array}{l}\text { COM421- } \\
\text { Survey of } \\
\text { Programm-ing } \\
\text { Languages } \\
\end{array}$ & $\sqrt{ }$ & $\sqrt{1}$ & $\sqrt{1}$ & $\sqrt{1}$ & $\sqrt{1}$ & $\sqrt{11}$ & 17 & $\sqrt{ }$ & $\sqrt{ }$ & $\sqrt{ }$ & $\sqrt{ }$ & $\sqrt{ }$ & $\sqrt{ }$ & $\sqrt{ }$ & $\sqrt{ }$ & $\sqrt{ }$ & $\sqrt{ }$ & $\sqrt{ }$ & $\sqrt{ }$ & $\mathrm{x}$ & $\sqrt{ }$ & $\sqrt{ }$ & $\mathrm{X}$ & $\mathrm{X}$ & $\mathrm{x}$ & $\mathrm{x}$ & $\mathrm{X}$ & $\mathrm{x}$ \\
\hline 27 & $\begin{array}{l}\text { COM422- } \\
\text { Computer } \\
\text { Graphics and } \\
\text { Animation }\end{array}$ & $\sqrt{ }$ & $\sqrt{1}$ & $\sqrt{1}$ & $\sqrt{3}$ & $\sqrt{1}$ & $\sqrt{ } \sqrt{1}$ & $1 \sqrt{ }$ & $\sqrt{ }$ & $\sqrt{ }$ & $\sqrt{ }$ & $\sqrt{ }$ & $\sqrt{ }$ & $\sqrt{ }$ & $\sqrt{ }$ & $\sqrt{ }$ & $\sqrt{ }$ & $\sqrt{ }$ & $\sqrt{ }$ & $\sqrt{ }$ & $\mathrm{x}$ & $\sqrt{ }$ & $\sqrt{ }$ & $\mathrm{x}$ & $\mathrm{x}$ & $\mathrm{x}$ & $\mathrm{x}$ & $\mathrm{X}$ & $\mathrm{x}$ \\
\hline 28 & $\begin{array}{l}\text { COM423- } \\
\text { Introduction to } \\
\text { Artificial } \\
\text { Intelligence and } \\
\text { Expert systems. } \\
\end{array}$ & $\sqrt{ }$ & $\sqrt{1}$ & $\sqrt{1}$ & $\sqrt{1}$ & $\sqrt{1}$ & $\sqrt{ }$ & $1 \sqrt{ }$ & $\sqrt{ }$ & $\sqrt{ }$ & $\sqrt{ }$ & $\sqrt{ }$ & $\sqrt{ }$ & $\sqrt{ }$ & $\sqrt{ }$ & $\sqrt{ }$ & $\sqrt{ }$ & $\sqrt{ }$ & $\sqrt{ }$ & $\sqrt{ }$ & $\mathrm{x}$ & $\sqrt{ }$ & $\sqrt{ }$ & $\mathrm{x}$ & $\mathrm{X}$ & $\mathrm{x}$ & $x$ & $\mathrm{x}$ & $\mathrm{x}$ \\
\hline 29 & $\begin{array}{l}\text { COM 424- } \\
\text { Professional } \\
\text { Practice in IT }\end{array}$ & $\sqrt{ }$ & $\sqrt{1}$ & $\sqrt{1}$ & $\sqrt{1}$ & $\sqrt{1}$ & $\sqrt{11}$ & 17 & $\sqrt{ }$ & $\sqrt{ }$ & $\sqrt{ }$ & $\sqrt{ }$ & $\sqrt{ }$ & $\sqrt{ }$ & $\sqrt{ }$ & $\sqrt{ }$ & $\sqrt{ }$ & $\sqrt{ }$ & $\sqrt{ }$ & $\sqrt{ }$ & $\mathrm{x}$ & $\sqrt{ }$ & $\sqrt{ }$ & $\mathrm{x}$ & $\mathrm{X}$ & $\mathrm{x}$ & $x$ & $\mathrm{X}$ & $\bar{x}$ \\
\hline 30 & $\begin{array}{l}\text { COM425- } \\
\text { Seminar on } \\
\text { current topics in } \\
\text { computing }\end{array}$ & $\sqrt{ }$ & $\sqrt{1}$ & $\sqrt{1}$ & $\sqrt{ }$ & $\sqrt{1}$ & $\sqrt{ } \sqrt{1}$ & $1 \sqrt{ }$ & $\sqrt{ }$ & $\sqrt{ }$ & $\sqrt{ }$ & $\sqrt{ }$ & $\sqrt{ }$ & $\sqrt{ }$ & $\sqrt{ }$ & $\sqrt{ }$ & $\sqrt{ }$ & $\sqrt{ }$ & $\sqrt{ }$ & $\sqrt{ }$ & $\mathrm{x}$ & $\sqrt{ }$ & $\sqrt{ }$ & $\sqrt{ }$ & $\mathrm{X}$ & $\mathrm{x}$ & $x$ & $\mathrm{X}$ & $\mathrm{x}$ \\
\hline 31 & $\begin{array}{l}\text { COM426 - } \\
\text { Small Business } \\
\text { Start Up }\end{array}$ & $\sqrt{ }$ & $\sqrt{1}$ & $\sqrt{1}$ & $\sqrt{1}$ & $\sqrt{1}$ & $\sqrt{1}$ & $\pi \sqrt{1}$ & $\sqrt{ }$ & $\sqrt{ }$ & $\sqrt{ }$ & $\sqrt{ }$ & $\sqrt{ }$ & $\sqrt{ }$ & $\sqrt{ }$ & $\sqrt{ }$ & $\sqrt{ }$ & $\mathrm{x}$ & $\mathrm{x}$ & $\sqrt{ }$ & $\mathrm{x}$ & $\sqrt{ }$ & $\mathrm{X}$ & $\sqrt{ }$ & $\mathrm{X}$ & $\sqrt{ }$ & $\sqrt{ }$ & $\sqrt{ }$ & $\sqrt{ }$ \\
\hline 32 & \begin{tabular}{|l|} 
COM429- \\
Project
\end{tabular} & $\sqrt{ }$ & $\sqrt{1}$ & $\sqrt{1}$ & $\sqrt{ }$ & $\sqrt{1}$ & $\sqrt{ } \sqrt{1}$ & $1 \sqrt{ }$ & $\sqrt{ }$ & $\sqrt{ }$ & $\sqrt{ }$ & $\sqrt{ }$ & $\sqrt{ }$ & $\sqrt{ }$ & $\sqrt{ }$ & $\sqrt{ }$ & $\sqrt{ }$ & $\sqrt{ }$ & $\sqrt{ }$ & $\sqrt{ }$ & $\mathrm{x}$ & $\sqrt{ }$ & $\sqrt{ }$ & $\sqrt{ }$ & $\mathrm{X}$ & $\mathrm{x}$ & $\mathrm{x}$ & $\sqrt{ }$ & $\sqrt{ }$ \\
\hline
\end{tabular}




\section{Conclusion and Recommendations}

\subsection{Conclusions}

The conclusions and recommendations for the study is drawn from the third-round data analysis as shown in Table 4 and results in Table 5. The results suggest that, there was significant difference in the views of academic and industry participant in the ranking of the skill and competency attributes based on the scale of preference. Therefore, our results show some consistency with other previous studies on the perception of academics versus the industry on the required employability skills of a graduates (Moreno et al. 2012; Jones et al. 2018; Scatalon et al. 2018; Mulder et al. 2006; Frezza et al., 2018; Dimopoulos 2018; Sarkar et al. 2016; Singh et al. 2014; Messum et al. 2017; Shivoro et al. 2018; Snoke \& Underwood 2002).

However, the peculiarity of our findings suggest that attributes involving Self-motivation, be technologically competent (ability to use current technology competently), Value the ethics of the profession, be able to participate in continuous learning and intellectual development, and Teamwork are consistently ranked higher than other attributes by the academics compared to that of the industry participants.

The industry consistently ranked the attributes of Knowledge of how business operates or structured; Understand profit motives of a business; Time management skills; and project management skills considered to be a motivation attributes (Soft-skills) which can be leant mostly outside the teaching of curriculum. This motivation attributes emphasized practical skills compared to the theoretical centered views (hard-skills) of the academics.

This finding suggests that (1) academics are more concerned with technical skills of an HND graduates of computer science, emphasizing graduates who are conversant with the use of latest technology and working with other rather than individuals. This is consistent with the curriculum currently being implemented (See section 5) which focus on acquisition of latest technologies in computing and in practical terms which involves working with others; (2) there is the need to incorporate those soft-skills which are the concerns of the industry through the already established entrepreneurship centers in the polytechnics and the one year mandatory industrial practice sponsored by Industrial Training Fund (a government agency) in other to reinforce the current curriculum for the training of HND computer science graduates. Previous studies have equally placed importance on understandings of profits motives of businesses and how business operates as a perquisite for evaluating the competences of a graduates as an employee (Snoke \& Underwood 2002; Okolie et al. 2019; Sarkar et al. 2016).

The difference in the views of academics and industry based on the results obtained reinforces the needs for serious collaborations between the industry and academics for development and maintenance of a more robust curricula for each course in computer science in other to improve the employability of graduates for the polytechnics system. Similar suggestion was given by Snoke \& Underwood (2002) for enhancing the course syllabi for information systems.

The limitations and possible threats to validity that can be considered for our study stem from the fact that, (1) our study sample was drawn from respondents within the academics in the polytechnics and some selected industry practitioners within the domain of our study, therefore, our results are limited to represent the educational and industry in this context; (2) there was slight drop in the response rates for second and third rounds of data collections (See Table 3 and Figure 1) which reduces the sample size upon which the first round analysis was conducted. Therefore, there is the possibility of our samples becoming unreliable or introducing some element of bias. However, the drop in the responses can be tolerated due to the fact that inferential analysis on the sampled element or population is not part of our scope (Blaikie 2003, p.168). Rather, our focus is on the participants who are expert in the field having consensus of opinions expected to converge at the third round and upon which our conclusions and recommendations were drawn; (3) there was time delays between rounds in data collection process, this can be attributed to the use of Delphi method compared to using the common survey (Skinner et al. 2015).

\subsection{Recommendations}

These two divergent views have created a serious gap for HND graduates in term of his/her employability which needs to be seriously addressed by all stakeholders (inclusive of the regulating authority and the professional bodies). If technical education will achieve its purpose and objectives, there is the need for complete handshake between the stakeholders. One way of achieving this, is the utilization of the various entrepreneurship center already established in the Polytechnics across the country with emphases on the skills acquisition in the core area of computing instead of the current practice of a trade skills outside the professional callings. Industry professional needs to be drafted into already established entrepreneurship centers within the Polytechnics to demonstrate to the would be graduates of computing (CS) how to achieve the motivational skills in practical terms for the radicalization of what had already been learnt in the various HND curriculum overtime. The lecturers are equally expected to do more in terms of practical contents as provided in the various curriculum being taught in the Polytechnics. The Polytechnics administration need to do more in terms of provision of 
computing facilities (hardware and software) for the laboratories compared to what is currently obtained in our Polytechnics across the six geo-political zones of the country. The regulating authority and professional bodies needs to carryout periodic (quarterly) visitation to Polytechnics to enforce standards rather than the present practice of waiting for five years of programme re-accreditation.

There is the need for establishment of Industrial Collaboration Center (Unit) in the polytechnics to close the gap in the divergent views of the two stakeholders to facilitates the exchange of ideas and information on the current theory and practice in computing. Although this study shows alignment of the current HND curriculum in CS with the needs of the industry in terms of the generic skills as indicated in Table 5. There is the need to adopt and adapt model developed by MacCallum \& Casey (2017), tagged " Skills Evidence and Evaluation Record (SEER) for evaluation and monitoring of HND CS student to determine the level of their preparation for work place based on the generic skills already acquired to make them employable in the industry. The aim of this model is to assist the students assess their personal skills and to proactively engage with employment opportunities in other to plan for their professional development needs. We equally suggest the adoption of Competency Learning Framework (CoLeaF) model developed by Frezza et al. (2018), to bridge the gap between curriculum center model e.g. MacCallum \& Casey (2017), and other competences such as social-emotional skills that a graduate need to possess in other to achieve some measure of total success. CoLeaF model has both inspirational and performance goals of a graduate programme (Aasheim 2009).

The two generic skills (1) "Sensitivity to differences in gender, culture and customs" and (2) "Adapt to unfamiliar cultures and operate in a socially and culturally diverse environment", considered to be of importance by the industry participant needs to be given serious consideration in the curriculum in other to improve the employability of the graduates in a plural society. When all the suggestions are critically looked into and possibly considered, the employability of HND graduates of CS will likely be achieved.

We suggest further studies to include (1) obtaining the views of students and graduates of HND in computer science on the skills and competences attributes use in this study for a comparison with that's of academics and industry; (2) Why the learning outcome of the present curriculum incorporate nearly all the basic attributes used in this study and yet there still exist skills and competences gaps in the employability of HND graduates. This will enable us determine whether the curriculum is better delivered by the academics or not and how any identified gaps could be used to meets the needs of the industry in terms of employments.

\section{References}

Aasheim, C. L., Li, L. \& Williams, S. (2009), "Knowledge and Skill Requirements for Entry-Level Information Technology Workers: A Comparison of Industry and Academia", Journal of Information Systems Education 20 (3), 349-356.

Abelha, M., Fernandes, S., Mesquita, D., Seabra, F. \& Ferreira-Oliveira, T. A. (2020), "Graduate Employability and Competence Development in Higher Education-A Systematic Literature Review Using PRISMA", Sustainability 12, 1-27.

Adebisi, A. T. (2015), "Acquisition of Entrepreneurial Skills by Polytechnic Students in Osun State. Nigeria", Journal of Educational and Social Research, 83-94.

Alvi, M. (2016), "A Manual for Selecting Sampling Techniques in Research".[Online] Available: https://mpra.ub.uni-muenchen.de/70218/ ( March 23, 2016)

Bhattacherjee, A. (2012), "Social Science Research: Principles, Methods, and Practices", Textbooks Collection. 3, Florida: Scholar Commons, University of South Florida.

Blaikie, N. (2003), "Analyzing Quantitative Data", 6 Bonhill Street, London: SAGE Publications.

Dimopoulos, A. (2018), "'From studies to employment' Significant factors that apart from job market shortage affect graduates'employability. The importance ofemployability-soft skills", MIBES Transactions 12 (1), 37-55.

Frezza, S. et al. (2018), "Modelling Competences for Computing Education Beyond 2020: A research based approach to defining competences in the computing disciplines", Proceedings of ACM ITiCSE Conference (ITiCSE 2018), 27.

Frezza, S. et al. (2018), "Modelling Competences for Computing Education Beyond 2020: a research-based approach to defining competences in the computing disciplines", In Rossling, G. and Scharlau, B. (eds.). Proceedings companion of the 23rd Innovation and technology in computer science education annual conference 2018 (ITiCSE 2018).

Hsu, C.-C. \& Sandford, A. B. (2007), "The Delphi Technique: Making Sense of Consensus", Practical Assessment, Research \& Evaluation 12(10), 1-8.

International Labour Organization. (2008), "Skills for improved productivity, employment growth and development (Report V)", International labour Conference, 97th Session (pp. 1-160). Geneva: International Labour Office.

International Organization for Migration. (2014), "Needs Assessment in the Nigerian Education Sector". Abuja: 
International Organization for Migration.

Jackson, K., Lower, L. C. \& Rudman, J. W. (2016), "The Crossroads between Workforce and Education", Perspectives in Health Information Management, 1-11.

Jones, S. K., Namin, S. A. \& Armstrong, E. M. (2018), "The Core Cyber-Defense Knowledge, Skills, and Abilities That Cybersecurity Students Should Learn in School: Results from Interviews with Cybersecurity Professionals", ACM Trans. Comput. Educ., 183.

Knighting, K., O’brien, M., Roe, B., Gandy, R., Lloyd-Williams, M., Nolan, M. \& Jack, B. (2016), "Gaining consensus on family carer needs when caring for someone dying at home to develop the Carers' Alert Thermometer (CAT): a modified Delphi study", Journal of Advanced Nursing 72(1), 227- 239.

Kumar, R. (2011), "Research Methodology a Step-by-Step guide for beginners", (3rd. ed.), 55 City Road, London: SAGE.

MacCallum, J. \& Casey, C. S. (2017), "Enhancing skills development and reflective practise in students durring their programme of study", New Directions in the Teaching of Physical Sciences 12(1).

Messum, D., Wilkes, L. \& Peters, C. (2017), "Senior managers' and recent graduates' perceptions of employability skills for health services management", Asia Pacific Journal of Cooperative Education, 18(2), $115-128$.

Moreno, M. A., Sanchez-Segura, M.-I., Medina-Dominguez, F. \& Carvajal, L. (2012), "Balancing software engineering education and industrial needs", Journal of Systems and Software 85(7), 16071620,https://doi.org/10.1016/j.jss.2012.01.060.

Mulder, M., Weigel, T. \& Collins, K. (2006), "The concept of competence concept in the development of vocational education and training in selected EU member states. A critical analysis", Journal of Vocational Education and Training 59(1), 65-85.

OECD . (2018), "The Future of Education and Skills 2030 projec", Paris, https://www.oecd.org > education > E2030 Position Paper (05.04.2018): OECD Publishing.

Okolie, U. C., Igwe, P. A., Eneje, B. C., Nwosu, H. \& Mlanga, S. (2019), "Enhancing Graduate Employability: Why Higher Education Institutions have problems with teaching generic skills?", Policy Future in Education, DOI:101177/1478210319864824.

Okoye, R. \& Arimonu, M. O. (2016 ), :Technical and Vocational Education in Nigeria: Issues, Challenges and a Way Forward", Journal of Education and Practice, 113-118.

Pandey, P. \& Pandey, M. M. (2015), "Research Methodology: Tools and Techniques", Romania: Bridge Center.

Sarkar, M., Overton, T., Thompson, C. \& Rayner, G. (2016), "Graduate Employability: Views of Recent Science Graduates and Employers", International Journal of Innovation in Science and Mathematics Education 24(3), 31-48.

Scatalon, L. P., Fioravanti, L. M., Prates, M. J., Garcia, R. E. \& Barbosa, E. F. (2018), "A survey on graduates' curriculum-based knowledge gaps in software testing", IEEE Frontiers in Education Conference (FIE), 1-8. doi: 10.1109/FIE.2018.8658688.

Sekaran, U. \& Bougie, R. (2011), "Research Methods for Business: A Skill Building Approach", 5th. ed . West Sussex, UK: Wiley.

Shivoro, R. I., Shalyefu, R. K. \& Kadhila, N. (2018), "Perspectives on Graduate Employability Attributes for Management Sciences Graduates", South African Journal of Higher Education 32(1), 216 - 232.

Showkat, N. \& Parveen, H. (2017), "Non-Probability and Probability Sampling". [Online] Available: https:/ /www.researchgate.net/publication/319066480 (August 11, 2017).

Singh, P., Thambusamy, X. R. \& Ramy, A. M. (2014), "Fit or Unfit? Perspectives of Employers and University Instructors of Graduates' Generic Skills", Social and Behavioural Sciences 123, 315 - 324.

Skinner, R., Nelson, R. R., Chin, W. W. \& Land, L. (2015), "The Delphi Method Research Strategy in Studies of Information Systems", Communications of the Association for Information Systems 37, 31-63.

Snoke, R. \& Underwood, A. (2002), "Generic Attributes of IS Graduates: An Analysis of Australian Views", In F. Tan, Advanced Topics in Global Information Management (pp. 370-384 ). Hershey, USA: Idea Group Publishing.

Winterton, J., Delamare-Le Deist, F. \& Stringfellow, E. (2006), "Typology of knowledge, skills and competences: clarification of the concept and prototype", Cedefop Reference series; 64. Italy: European Centre for the Development of Vocational Training. 